(c) American Dairy Science Association, 2004.

\title{
Dietary Preference of Dairy Cows Grazing Ryegrass and White Clover
}

\author{
S. M. Rutter, R. J. Orr, N. H. Yarrow, and R. A. Champion \\ Institute of Grassland and Environmental Research, \\ North Wyke, Okehampton, Devon, EX20 2SB, \\ England, UK
}

\begin{abstract}
The dietary preference of lactating dairy cows grazing perennial ryegrass (Lolium perenne $\mathrm{L}$.) and white clover (Trifolium repens L.) was studied. Twelve groups of 2 lactating, Holstein-Friesian dairy cows grazed 1.2-ha plots containing conterminal monocultures of clover and grass. Half of the groups grazed a plot containing $75 \%$ clover and $25 \%$ grass (by ground area), with the remaining groups grazing a plot containing $25 \%$ clover and $75 \%$ grass. The intake rates of clover were higher than those of grass, and intake rates were higher in the evening than in the morning. During daylight hours, clover formed $63.2 \%$ of the diet of the groups offered $25 \%$ clover, which was higher than the $25 \%$ offered but lower than preference for $100 \%$ clover. This indicated that cows showed a partial preference for clover, with an overall value (i.e., the mean of the $75 \%$ and $25 \%$ clover groups) of $73.8 \%$. There was a diurnal pattern to preference, with a stronger preference for clover in the morning and with the preference for grass increasing during the day. The basis for partial preference remains unclear and warrants further research.
\end{abstract} (Key words: grazing, dairy cow, behavior, legume)

Abbreviation key: $\mathbf{C 2 5}=\mathbf{2 5} \%$ clover, $75 \%$ grass treatment; $\mathbf{C 7 5}=75 \%$ clover, $25 \%$ grass treatment; $\mathbf{S S H}=$ sward surface height.

\section{INTRODUCTION}

The efficient utilization of pasture by grazing livestock requires an understanding of preference and selection by grazing animals. The influence of selective grazing is important both in the short term, in relation to the quality of the diet consumed, and in the long term, because of feedback effects on pasture composition (Hodgson and Illius, 1996). This is becoming in-

Received May 6, 2003.

Accepted November 11, 2003.

Corresponding author: S. M. Rutter; e-mail: mark.rutter@ bbsrc.ac.uk. creasingly important in many temperate grasslandbased livestock systems with an increasing incorporation of legumes into grass swards. These swards are generally grazed as an intimate mixture of 2 herbage species, giving the animals a choice of what to eat. In this situation, the animals need to search for their preferred feed within the mixture (i.e., there is a physical constraint). This constraint will, to some extent, affect what the animals select. To study what animals want to eat (i.e., their preference), selection must be measured in a situation with minimal physical constraints (Newman et al., 1995). This is usually achieved by grazing the 2 herbage species as spatially separate but adjacent monocultures, with the animals given a free choice to graze either grass or clover whenever they want. This approach was taken in this study. Previous studies using this approach have shown that both sheep (Parsons et al., 1994) and dairy heifers (Cosgrove et al., 1996; Rutter et al., 2003) showed a partial preference for white clover (Trifolium repens L.) when given a choice between white clover and perennial ryegrass (Lolium perenne L.). Parsons et al. (1994) reported a strong diurnal pattern to the preference and a decline in clover content over the course of the day, with a return to high clover content the following morning. Rutter et al. (2004) reported a similar finding with heifers, although the effect was less marked than with sheep. The aim of the study reported here was to investigate the diet preference of lactating dairy cows grazing adjacent monocultures of perennial ryegrass and white clover.

\section{MATERIALS AND METHODS}

\section{Sward Establishment}

Perennial ryegrass (cv. Parcour) and white clover (cv. Kent Wild White) were sown in September 1996 in two 1.2-ha plots containing conterminal monocultures of clover and grass. The grass areas received a total of $240 \mathrm{~kg} / \mathrm{ha}$ of $\mathrm{N}, 60 \mathrm{~kg} / \mathrm{ha}$ of $\mathrm{P}_{2} \mathrm{O}_{5}$, and $60 \mathrm{~kg} / \mathrm{ha}$ of $\mathrm{K}_{2} \mathrm{O}$. The clover areas received a total of $25 \mathrm{~kg} / \mathrm{ha}$ of N, 108 $\mathrm{kg} / \mathrm{ha}$ of $\mathrm{P}_{2} \mathrm{O}_{5}$, and $108 \mathrm{~kg} / \mathrm{ha}$ of $\mathrm{K}_{2} \mathrm{O}$. The grass and clover areas were cut to a height of $6 \mathrm{~cm} 12 \mathrm{~d}$ before 
the start of the study. The plots were grazed by dairy cows that were not part of the study before the start of each measurement period to a mean sward surface height (SSH) of $10.4 \mathrm{~cm}$ (range 8.1 to $12.3 \mathrm{~cm}$ ).

\section{Animals}

Twenty-four lactating Holstein-Friesian cows were allocated at random to 12 groups, each of 2 animals. The cows calved between January and March, and the preference measurements were conducted approximately 6 mo after calving. The cows were milked $2 \times$ per day, during which time they were removed from the grazed paddocks from approximately 0650 to 0805 $\mathrm{h}$ and 1540 to $1625 \mathrm{~h}$ (British Summer Time). The cows received $4 \mathrm{~kg}$ of concentrate per day, offered in-parlor in 2 equal amounts, one at each milking. The concentrate provided $183 \mathrm{~g}$ of $\mathrm{CP}$ and 11.3 MJ of metabolizable energy per kilogram fresh weight and contained 0.150 barley, 0.125 wheat, 0.225 corn gluten, 0.075 molasses, 0.120 rapeseed meal extracted, 0.125 soya 48 extract, 0.125 dried citrus pulp, 0.020 fat, 0.025 dairy mineral mix, and 0.010 limestone, by proportion on a fresh weight basis. Starting $2 \mathrm{~d}$ before the cows were given access to clover swards, they were given poloxalene (in the form of Bloat Guard Premix, Agrimin Limited, Brigg, South Humberside, UK) to help prevent ruminal tympany. This was achieved by feeding $19 \mathrm{~g}$ of poloxalene mixed with $11 \mathrm{~g}$ of molasses and placed on top of the concentrates in the in-parlor feeders at each milking.

\section{Treatments}

Each group of 2 cows was allocated to one of 2 treatments (i.e., there were 6 groups per treatment). Both treatments consisted of grazing adjacent grass and clover monocultures. One treatment consisted of $75 \%$ clover and $25 \%$ grass $(\mathbf{C 7 5})$ and the other $25 \%$ clover and $75 \%$ (C25) grass by ground area. The 2 treatments, C25 and $\mathrm{C} 75$, were used to ensure that the study could distinguish between grazing at random and active preference by the cows to eat a mixed diet. For example, if only one treatment had been used (e.g., $50 \%$ grass and $50 \%$ clover), and the animals had selected a diet of $50 \%$ clover and $50 \%$ grass, it would have been impossible to tell whether this was due to active selection for a mixed diet or grazing at random. The total area grazed under each treatment was $1.2 \mathrm{ha}$, with the "75\%" areas being approximately $93 \times 96 \mathrm{~m}$ and the "25\%" areas being 31 $\times 96 \mathrm{~m}$, with a $96-\mathrm{m}$ boundary between the 2 . Each treatment paddock had one water trough that was positioned halfway along the grass/clover boundary. The animals entered the treatment paddocks on the grass/ clover boundary each time they returned from milking to prevent any bias in their subsequent grazing behavior.

\section{Preference Measurements}

Preference was tested in 6 successive measurement periods on 28 July, 4 August, 13 August, 23 August, 3 September, and 11 September (1997). In the week prior to the start of each preference measurement period, the cows grazed a 1.8-ha paddock that comprised an area of pure grass alongside an equal-sized area of pure clover (i.e., adjacent monocultures). This had a $130-\mathrm{m}$ boundary between the grass and the clover areas, and a single water trough was positioned halfway along this boundary. The diet selected by each of the 2 cows in each group was recorded by direct visual observation using scan sampling at 2-min intervals. The observers recorded whether the cows were eating, ruminating, or idling (i.e., neither eating nor ruminating); the observers also recorded which herbage species the animals were on and whether they were lying or standing. Observations were made from a raised, covered hide positioned at the end of the border between the grass and clover for each of the 2 test paddocks. This gave the observers a clear view of where the animals were grazing without disturbing them. The preference measurement period started immediately after morning milking on $\mathrm{d} 1$ and finished immediately before morning milking on d 3 (i.e., it lasted approximately $48 \mathrm{~h}$ in total). Observations were recorded during the hours of daylight (on average between 0540 and $2105 \mathrm{~h}$, British Summer Time). During the observation periods, the cows were fitted with IGER Behavior Recorders (Rutter et al., 1997) to record their jaw movements. The recorders were fitted just before the start of the observation period (i.e., immediately after morning milking on the $\mathrm{d} 1$ ). The battery and memory cards in the recorders were changed immediately after morning milking on the $d$ 2 , and the recorders were removed after morning milking on the $d$ 3. These jaw movement recordings were analyzed using the "Graze" analysis software (Rutter, 2000 ) to determine when the animals were eating. This allowed any eating that occurred during the hours of darkness (i.e., when the cows were not being manually observed) to be identified.

\section{Estimation of Preference Based on Total Herbage Intake}

Preference can be calculated either as the proportion of time spent grazing each species, or as the proportion of intake derived from each species (Parsons et al., 1994). Given that total intake is more important than grazing time in terms of the energy balance of the ani- 
mal, the analysis of preference in this study was based on total herbage intake. The intake of grass and clover were estimated by multiplying grazing times by the appropriate intake rate (see below). Grass intake rates were applied to the minutes spent eating grass in each hour of the day, and the clover intake rates to the minutes eating clover in each hour, as identified by the manual observers. The morning and afternoon intake rates for the 2 herbage species were applied to the relevant hours of the day. These were determined by taking the average midpoints of the intake rate measurement periods, which were 1000 and $1800 \mathrm{~h}$, and applying the appropriate intake rates to the periods of the day that started and stopped at the equidistant points in time between them. This meant that the morning intake rates were applied to the period between 0200 and 1400 $\mathrm{h}$ and the afternoon intake rates to the period between 1400 and $0200 \mathrm{~h}$.

Although analysis of the automatic jaw movement recordings allowed grazing that occurred during the hours of darkness to be recorded, the automatic system was unable to record whether this was on grass or clover. Grazing at night also formed a low proportion of the total grazing time (see the Results section). Consequently, grazing at night was excluded from the analysis of preference.

\section{Intake Rate Measurements}

The intake rates of selected cows were measured at 2 times of day on each of the 2 herbages on 4 separate occasions during the study. The measurements were made following morning and afternoon milking, using the technique described by Penning and Hooper (1985) and modified for use with cattle (Huckle et al., 1994). This involved weighing the cows before and after a period of approximately $1 \mathrm{~h}$ grazing, during which time the cows were fitted with bags to collect feces and urine to ensure that these did not constitute a weight loss. The cows were also fitted with IGER Behavior Recorders (Rutter et al., 1997) to record jaw movements during the intake rate measurement period. These grazing measurements were made between approximately 0930 and $1030 \mathrm{~h}$ and approximately 1740 and $1840 \mathrm{~h}$ (British Summer Time). Prior to the grazing measurements, the cows were weighed before and after a period of approximately $1 \mathrm{~h}$, during which they were fitted with a muzzle to prevent grazing and allowed to walk within the paddock. This allowed insensible weight loss to be calculated and applied as a correction to the grazing period measurements. Herbage DM was measured by taking pluck samples from the grazed horizon that were representative of the material selected by the cows. This sample was oven-dried at $80^{\circ} \mathrm{C}$ for $20 \mathrm{~h}$. The jaw movement recordings were subsequently analyzed using the "Graze" analysis software (Rutter, 2000) to identify the exact eating time (Gibb, 1998) during the 1-h grazing period.

\section{Calculating Total Daily Eating Time and Herbage Intake}

Mean total time (minutes) spent eating during daylight hours (i.e., on both species) over the 48 -h period was calculated. The mean DMI (kilograms) during daylight hours was also calculated. The mean time spent eating during the hours of darkness (i.e., between the time of the last manual observation at night and the first observation the following morning) was taken from the analysis of the automatic recordings using the "Graze" software. Calculating intake during the hours of darkness was more complicated, as it was not known whether night grazing occurred on grass or clover. Given that the intake rate of grass was lower than that of clover, maximum and minimum intakes were calculated: the minimum assuming the animals ate only grass and the maximum assuming they ate only clover. The true value of intake during the hours of darkness would have fallen between these 2 values. Intake during the hours of darkness was calculated as described earlier (i.e., by multiplying grazing time before and after $0200 \mathrm{~h}$ by the appropriate intake rate).

\section{Statistical Analysis}

Given that individual animals in a group cannot necessarily be regarded as statistically independent (Rook and Penning, 1991), the mean of the measurements from the 2 cows in each group were used for the statistical analyzes. The intake rates of grass and clover at the 2 times of day were analyzed by ANOVA using the statistical package GenStat (GenStat Committee, 2000) with herbage species (i.e., grass or clover) and time of day as fixed effects and group as a random effect. Preference for clover was analyzed as the angular transformed percentage of total herbage intake derived from clover. Next $t$-tests were performed to see whether the proportion of clover in the diet of the cows was significantly different to the proportion they were offered (by ground area), to indicate whether the cattle were grazing at random. Then $t$-tests were also performed to see whether the proportion of clover in the diet of the cows was significantly different to either 0 or $100 \%$, to indicate whether any preference was absolute or partial.

Preference during daylight hours when no grazing occurred was estimated using the GenStat (GenStat Committee, 2000) procedure ANTMVESTIMATE, which estimates missing values in repeated measures 


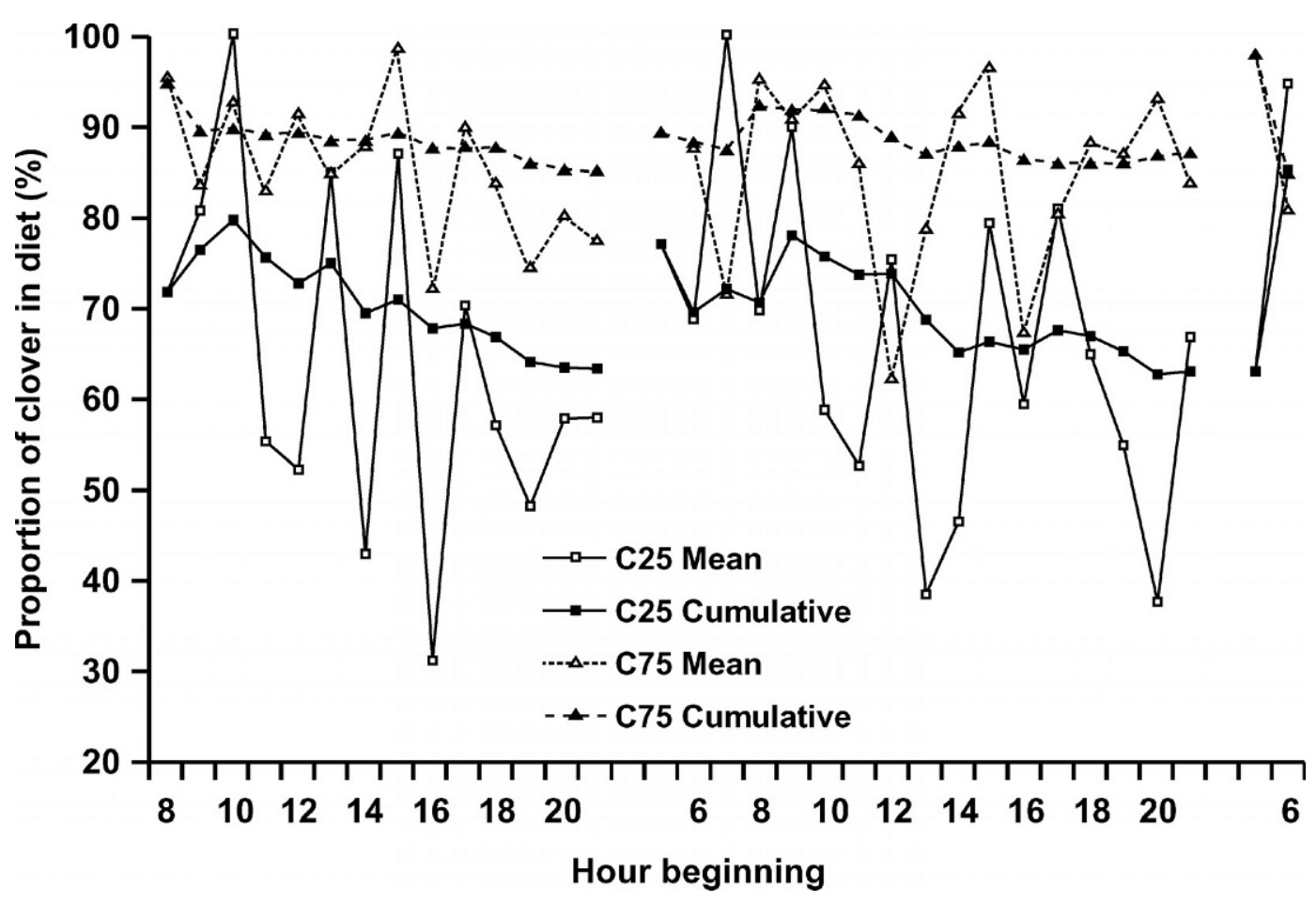

Figure 1. Temporal pattern of preference for clover in dairy cows grazing adjacent grass and clover moncultures. Open symbols and lightweight lines indicate the mean hour-by-hour preference for clover over the course of the observation period. Solid symbols and heavyweight lines indicate the cumulative percentage time spent grazing clover from the start of each observation period. In both cases, the solid line and square symbols denotes the $\mathrm{C} 75^{1}$ treatment, and the dotted line and triangle symbols denote the $\mathrm{C} 25^{2}$ treatment. ${ }^{1} \mathrm{C} 75=75 \%$ clover, $25 \%$ grass treatment. ${ }^{2} \mathrm{C} 25=25 \%$ clover, $75 \%$ grass treatment.

designs (Kenward, 1994). The antedependence order of the repeated measures preference data was then determined using the ANTORDER procedure in GenStat, and an order of 2 was found to be appropriate. This meant that the current observations were dependent on the previous $21-\mathrm{h}$ periods. The data were therefore split into 3 "days" for data analysis (i.e., from the start of observations until dusk on the d 1 of observation, from dawn to dusk on the $\mathrm{d} 2$, and from dawn until the end of observations on $d$ 3). The preference in each hour of each day was analyzed using ANOVA, with no covariate for the $h 1$, the $h 1$ as a covariate for the $h$ 2 , and with the proceeding $2 \mathrm{~h}$ as covariates for the subsequent hours in the period. Orthogonal polynomials were formed (using the VORTHPOLYNOMIAL command in GenStat) over time within each of the days, and analyzed using ANOVA to test for any diurnal pattern to preference using the proportion of clover offered as the treatment.

\section{RESULTS}

\section{Preference}

Clover formed $63.0 \%$ of the total herbage intake of group $\mathrm{C} 25$, which was greater than both selection for the $25 \%$ clover they were offered $(t=5.11, \mathrm{df}=5, P=$ $0.004)$ and selection for $0 \%$ clover $(t=11.74, \mathrm{df}=5, P$ $<0.001)$ and was less than selection for $100 \%$ clover $(t=-8.13, \mathrm{df}=5, P<0.001)$. Clover formed $84.5 \%$ of the total herbage intake of group $\mathrm{C} 75$, which was not significantly different from the $75 \%$ clover they were offered ( $t=1.60, \mathrm{df}=5, P=0.169)$ but was less than selection for $100 \%$ clover $(t=-3.36, \mathrm{df}=5, P=0.020)$ and more than selection for $0 \%$ clover $(t=11.54, \mathrm{df}=$ $5, P<0.001)$.

There was a decline in the preference for clover over the course of the day (Figure 1), shown in the analysis of the orthogonal polynomial contrasts that were formed from the hour-by-hour preference data, which showed a cubic contrast on $\mathrm{d} 1\left(\mathrm{~F}_{1,11}=5.21, P=0.046\right)$ and linear $\left(\mathrm{F}_{1,11}=9.26, P=0.012\right)$ and quadratic $\left(\mathrm{F}_{1,11}=\right.$ $5.43, P=0.042$ ) contrasts on $d 2$. ANOVA of the hourby-hour preference data showed differences in the percentage of clover in the diet between the $\mathrm{C} 25$ and C75 treatments for $3 \mathrm{~h}$ out of the $33 \mathrm{~h}$ of observation (Table 1). On 2 of these occasions (in the hours beginning 1200 and $2000 \mathrm{~h}$ on $\mathrm{d} 2$ ), the percentage of clover eaten by C25 was higher than $\mathrm{C} 75\left(\mathrm{~F}_{1,11}=15.6, P=0.003 ; \mathrm{F}_{1,11}=\right.$ $7.58, P=0.022$ ). On the third occasion (the hour beginning $0600 \mathrm{~h}$ on $\mathrm{d} 3$ ), the percentage of clover eaten by 
Table 1. Summary of the hour-by-hour analysis of the preference results. The data were analyzed as the angular transformed percentage clover in the diets of the cows. Note that the table gives the mean values after an inverse angular transformation has been applied (i.e., they are expressed in the original percentage units). The standard errors are from the angular transformed values. $P$ values less than 0.05 are shown in bold.

\begin{tabular}{|c|c|c|c|c|}
\hline \multirow{2}{*}{$\begin{array}{l}\text { Hour } \\
\text { beginning }\end{array}$} & \multicolumn{2}{|c|}{ Mean percentage clover } & \multirow[b]{2}{*}{ Standard error } & \multirow[b]{2}{*}{$P$} \\
\hline & $\mathrm{C} 25^{1}$ & $\mathrm{C} 75^{2}$ & & \\
\hline \multicolumn{5}{|l|}{ Day 1} \\
\hline 0800 & 60.2 & 99.4 & 11.5 & 0.061 \\
\hline 0900 & 89.5 & 82.4 & 14.7 & 0.784 \\
\hline 1000 & 100.0 & 93.4 & 5.2 & 0.065 \\
\hline 1100 & 53.3 & 68.4 & 15.1 & 0.686 \\
\hline 1200 & 51.7 & 82.1 & 14.9 & 0.394 \\
\hline 1300 & 69.1 & 89.5 & 9.4 & 0.290 \\
\hline 1400 & 66.6 & 75.5 & 9.5 & 0.686 \\
\hline 1500 & 94.1 & 78.5 & 8.4 & 0.279 \\
\hline 1600 & 21.3 & 83.3 & 12.2 & 0.052 \\
\hline 1700 & 74.1 & 94.2 & 5.5 & 0.062 \\
\hline 1800 & 67.8 & 77.7 & 10.8 & 0.683 \\
\hline 1900 & 59.7 & 76.8 & 12.9 & 0.574 \\
\hline 2000 & 59.2 & 53.3 & 14.1 & 0.866 \\
\hline 2100 & 72.8 & 44.8 & 8.5 & 0.202 \\
\hline \multicolumn{5}{|l|}{ Day 2} \\
\hline 0500 & 69.7 & 96.6 & 7.3 & 0.051 \\
\hline 0600 & 95.3 & 88.6 & 7.1 & 0.498 \\
\hline 0700 & 50.0 & 97.8 & 11.6 & 0.054 \\
\hline 0800 & 58.5 & 66.8 & 15.5 & 0.826 \\
\hline 0900 & 65.6 & 51.1 & 12.5 & 0.640 \\
\hline 1000 & 27.5 & 85.9 & 13.5 & 0.089 \\
\hline 1100 & 46.0 & 93.1 & 12.0 & 0.091 \\
\hline 1200 & 96.4 & 42.0 & 6.9 & 0.003 \\
\hline 1300 & 55.2 & 62.1 & 15.2 & 0.844 \\
\hline 1400 & 63.1 & 86.8 & 11.6 & 0.350 \\
\hline 1500 & 77.7 & 74.7 & 13.5 & 0.915 \\
\hline 1600 & 55.4 & 90.4 & 9.3 & 0.104 \\
\hline 1700 & 37.9 & 53.3 & 14.3 & 0.673 \\
\hline 1800 & 56.3 & 12.4 & 14.1 & 0.192 \\
\hline 1900 & 60.9 & 86.7 & 6.5 & 0.090 \\
\hline 2000 & 93.6 & 28.2 & 11.1 & 0.022 \\
\hline 2100 & 92.9 & 66.4 & 9.7 & 0.182 \\
\hline \multicolumn{5}{|l|}{ Day 3} \\
\hline 0500 & 85.2 & 41.2 & 12.9 & 0.163 \\
\hline 0600 & 56.8 & 89.4 & 6.0 & 0.028 \\
\hline
\end{tabular}

${ }^{1} \mathrm{C} 25=25 \%$ clover, $75 \%$ grass treatment.

${ }^{2} \mathrm{C} 75=75 \%$ clover, $25 \%$ grass treatment.

C75 was higher than $\mathrm{C} 25\left(\mathrm{~F}_{1,11}=6.83, P=0.028\right)$. The results from the analysis of covariance for all of the hours in each of the $3 \mathrm{~d}$ showed significant differences between $\mathrm{C} 25$ and $\mathrm{C} 75$ in the second $\left(\chi^{2}=35.70, \mathrm{df}=\right.$ $16, P=0.003)$ and third periods $\left(\chi^{2}=6.88, \mathrm{df}=2, P=\right.$ $0.032)$ but not in the first $\left(\chi^{2}=19.40, \mathrm{df}=14, P=0.150\right)$.

\section{Intake Rates}

Intake rates (Table 2) were higher for cows grazing clover than for cows grazing grass $\left(\mathrm{F}_{1,15}=26.63, P<\right.$ 0.001 ) and were higher in the evening than the morning $\left(\mathrm{F}_{1,15}=8.15, P=0.019\right)$. There was no significant interaction between sward and time of day $\left(\mathrm{F}_{1,15}=0.23, \mathrm{NS}\right)$.
Table 2. Herbage intake rates ( $\mathrm{g} / \mathrm{min}$ of $\mathrm{DM})$ for grass and clover at 2 different times of day.

\begin{tabular}{lllll}
\hline & & \multicolumn{2}{c}{ Time of day } & \\
\cline { 3 - 4 } & & Morning & Afternoon & Mean \\
\hline Herbage & Grass & 24.3 & 30.7 & 27.5 \\
& Clover & 36.8 & 45.7 & 41.3 \\
& Mean & 30.6 & 38.2 & \\
\hline
\end{tabular}

\section{Total Eating Times and Herbage Intakes}

Mean total eating time during the hours of daylight each day (both grass and clover) was $430 \mathrm{~min}$, with a mean combined intake of grass and clover during this period of $15.7 \mathrm{~kg}$ of DM. The cows spent a mean of 48 min eating during the hours of darkness, during which time their herbage intakes would have been in the range 1.41 to $2.12 \mathrm{~kg}$ of DM (depending on the proportion of grass or clover eaten during this period). These give a mean total daily grazing time of $478 \mathrm{~min}$ and a mean total daily intake of between 17.12 and $17.83 \mathrm{~kg}$ of DM. Eating at night represented $10.1 \%$ of the total daily eating time.

\section{DISCUSSION}

Clover formed $63.2 \%$ of the diet of the C25 cows, which was significantly more than the $25 \%$ they were offered. This indicates that these cows showed active selection for clover (i.e., that they were not grazing at random). Cows under both the $\mathrm{C} 25$ and $\mathrm{C} 75$ treatments selected significantly more than $0 \%$ clover and significantly less than $100 \%$ clover, even though they could have easily selected $100 \%$ of either species over the 48 $\mathrm{h}$ observation period. These results indicate that preference for clover was partial and not absolute. Note that the $84.5 \%$ clover in the diet of the C75 cows was very close to the $75 \%$ they were offered and consequently no significant differences were detected between these values in this study. The mean preference for clover for the $\mathrm{C} 25$ and the $\mathrm{C} 75$ cows was $73.8 \%$, suggesting that this is what cows would select if offered $50 \%$ clover and 50\% grass (by ground area). This figure is slightly higher than the figures reported previously for dairy heifers of $63.9 \%$ (Rutter et al., 2004) and 50 to 65\% (Cosgrove et al., 1996). The figure is also within the range of 65 to $74 \%$ for sheep reported previously by Parsons et al. (1994). The hour-by-hour analysis of the preference results showed significant treatment effects in only $3 \mathrm{~h}$ of the $33 \mathrm{~h}$ recorded, which could have occurred by chance. Consequently these results will not be discussed any further. However, the analysis of all of the hours in each of the $3 \mathrm{~d}$ showed significant differ- 
ences between the $\mathrm{C} 25$ and $\mathrm{C} 75$ treatments, showing that relative abundance influences the preference of dairy cattle; similar results have also been reported for sheep (Parsons et al., 1994).

\section{Diurnal Pattern of Preference}

The significant decline in preference for clover over the course of the day is similar to that reported for sheep (Parsons et al., 1994). To facilitate comparison with the study of Parsons et al. (1994), Figure 1 includes the cumulative percentage of clover in the diet of the cows in this study. The slopes of these lines with lactating dairy cows are similar to those for lactating ewes from a grass/clover background. The similarities in the diurnal pattern and partial preference for clover between cattle and sheep, which were also of different ages and physiological states, suggest a common biological basis for diet selection in these species.

The intake rate of clover was higher than that of grass, and it is possible that this is why the cows in this study preferred the clover (i.e., the cows preferred clover because they could eat it quickly). However, it is also possible that the intake rate of the clover was higher because it was the preferred herbage (i.e., the cows ate clover quickly because they preferred it). That is, it is not clear which was cause and which effect. Illius et al. (1999) studied diet selection by goats of different grasses. They argued that intake rate was largely independent of preference and was primarily affected by the biomass density in the grazed stratum. They concluded that the goats in their study selected diets that tended to maximize intake rates (i.e., that animals preferred a herbage because they could eat it quickly).

\section{Why Do Ruminants Eat Mixed Diets?}

Whatever the causality of preference, the results from this and other studies raise the question of why herbivores eat mixed diets. If the animals in this study simply wanted to maximize their intake (either total daily intake or intake per unit eating time), they should have eaten just clover. Note that the available clover herbage mass on both treatments was sufficient for the total daily intake over the 48-h study period to be achieved from the clover monoculture alone had the animals wanted. Various possible explanations for mixed diets in herbivores have been proposed, as discussed below.

One possible explanation of mixed diets in herbivores is "matching" (Senft et al., 1987). This relates the ratio of reward rates with the ratio of food types in the animal's diet. When applied to the foraging behavior of individual animals, matching only refers to allocation between 2 depleting alternatives, when it is the ratemaximizing strategy (Illius et al., 1999). Although the short-term nature of the 48-h observation periods in this study ensured that resource depletion did not limit choice, the cows could not have anticipated this, and may have adopted a matching foraging strategy based on previous experience of grazing clover to depletion. The ratio of clover intake rate/grass intake rate for the morning and evening were 1.51 and 1.49 , respectively (Table 2), and had the cows shown perfect matching, they should have shown a preference for clover of approximately 60\% (from Figure 2 in Illius et al., 1999). Given that the preference for clover in C75 was higher ( $t=3.13, P=0.026$ ) than this, it is clear that the cows in this treatment were overmatching. That is, there was a higher proportion of clover in their diet than would be expected given the relative intake rates of the 2 herbage species. Consequently, matching cannot explain the mixed diets observed in this study.

Illius et al. (1999) argued that discrimination error is likely to be a general explanation of mixed diets in herbivores, regardless of whether other explanations also apply. Edwards et al. (1997) showed that sheep could discriminate between turfs of ryegrass and white clover by sight or smell alone, without the need to taste them, and this suggests that discrimination error does not account for mixed diets in sheep. Howery et al. (2000) showed that cattle can learn to associate traffic barricades and cones with different quality foods and concluded that they can learn to associate visual cues with disparate food qualities. However, the visual acuity of cattle (Entsu et al., 1992) is between one-quarter and one-sixth that of sheep (Piggins and Phillips, 1996), so it is possible that cattle lack the visual acuity to discriminate between grass and clover by sight alone. Consequently, further research is needed to establish whether discrimination error accounts for mixed diets in grazing cattle. However, given the similarities in diurnal pattern and the partial preference for grass and clover in sheep and cattle, and given that sheep can discriminate between grass and clover, discrimination error is not a very compelling explanation of mixed diets in cattle.

Another possible explanation for mixed diets in ruminants is the need to maintain effective rumen function (Rutter et al., 2000). Cattle and sheep have evolved primarily to be grazers of grass, and their digestive system includes the rumen in which microorganisms digest the cellulose that forms a major part of their fibrous diet (Albright and Arave, 1997). Although cattle can be kept on pure clover diets without problems (e.g., Rutter et al., 2002), it is likely that this will result in a change in the proportions of the different microorgan- 
isms in their rumen compared with animals that maintain some grass in their diet. This would probably lead to a reduction in the efficiency of the digestion of grass in the animals that ate only clover compared with animals that also ate some grass. This would put the animals that had eaten only clover at a competitive disadvantage (compared with those that had eaten some grass) should, for example, reduced availability of clover force them to start grazing grass again. This evolutionary pressure to optimize the ability to cope with change could account for why cattle and sheep eat mixed diets. Intriguingly, Merry et al. (2002) found that the in vitro efficiency of microbial protein synthesis from mixtures containing different proportions of red clover and grass silages was highest with $70 \%$ red clover and $30 \%$ grass. It is possible, therefore, that the animals were eating mixed diets containing approximately $70 \%$ clover in order to optimize microbial protein synthesis. This could have implications for reducing $\mathrm{N}$ pollution from grazed grass/clover swards, and the relationships between diet preference and rumen function clearly warrant further research.

Newman et al. (1995) gave one of the most compelling explanations of mixed diets in ruminants related to perceived predation risk. Although the cattle studied in the experiment reported here were not exposed to carnivorous predators, Lima and Dill (1990) argue that the perceived risk of predation is an important factor influencing animal behavior, including foraging. Although predation has been clearly important in evolutionary time, growing evidence suggests that it can influence animal behavior in ecological time. One response to the perceived risk of predation is to avoid grazing at night, when the cows' ability to detect possible predatory attacks is reduced. The animals can minimize the need to graze at night by grazing forage with a slower rate of digestion and lower passage rate (i.e., by grazing grass in the evening rather than clover, which has a higher passage rate than grass). This possible antipredation strategy (Penning et al., 1998) could explain the diurnal pattern to preference reported in this and other studies (Parsons et al., 1994; Rutter et al., 2004) and warrants further research.

\section{Total Daily Eating Times and Intake}

The total daily eating times of the cows in this study (479 $\mathrm{min}$ ) were between those reported by Orr et al. (2001) for lactating dairy cows strip-grazing grass (462 min) and by Gibb et al. (1999) for cows under continuous variable stocking on grass at $9-\mathrm{cm}$ SSH (528 min). The total daily herbage intake of the lactating dairy cows in this study (between 17.1 and $17.8 \mathrm{~kg} / \mathrm{d}$ of $\mathrm{DM}$ ) is similar to that reported by Orr et al. (2001) for cows strip-grazing grass (18.0 kg/d of DM), but it is higher than that reported by Gibb et al. (1999) for lactating dairy cows under continuous variable stocking on grass at $9-\mathrm{cm} \mathrm{SSH}(14.6 \mathrm{~kg} / \mathrm{d}$ of DM). This reflects that the 48-h grazing period following regrowth used in this study gave grazing conditions with more in common with strip grazing than continuous variable stocking. Further research is needed to ascertain whether the relatively high daily herbage intakes recorded in this study could be maintained under continuous variable stocking conditions on adjacent grass and clover monocultures in the long-term (i.e., over the course of several weeks).

\section{CONCLUSIONS}

The dairy cows showed a mean partial preference for white clover of $74 \%$, even though greater intakes could have been obtained by eating only clover. There was a clear diurnal pattern to preference, with the proportion of time spent eating perennial ryegrass being higher in the evening than the morning. These results are similar to those reported for sheep (Parsons et al., 1994) and dairy heifers (Rutter et al., 2004). Further research is required if we are to understand why both sheep and cattle choose to eat mixed diets when given a choice of grass and clover.

\section{ACKNOWLEDGMENTS}

Dan Dhanoa provided advice on statistical analysis, and Ruth Nuthall helped analyze the night grazing. This work was funded by the UK Department for Environment, Food, and Rural Affairs (formerly Ministry of Agriculture, Fisheries, and Food). The Institute of Grassland and Environmental Research is supported through the Biotechnology and Biological Sciences Research Council. This research was carried out in accordance with the welfare standards approved by the Institute of Grassland and Environmental Research's Ethical Review Procedure.

\section{REFERENCES}

Albright, J. L., and C. W. Arave. 1997. The Behaviour of Cattle. CAB International, Wallingford, UK.

Cosgrove, G. P., C. B. Anderson, and R. H. Fletcher. 1996. Do cattle exhibit a preference for white clover? Agron. Soc. N. Z. 11:83-86.

Edwards, G. R., J. A. Newman, A. J. Parsons, and J. R. Krebs. 1997. Use of cues by grazing animals to locate patches: an example with sheep. Appl. Anim. Behav. Sci. 51:59-68.

Entsu, S., H. Dohi, and A. Yamada. 1992. Visual acuity of cattle determined by the method of discrimination learning. Appl. Anim. Behav. Sci. 34:1-10.

GenStat Committee. 2000. GenStat Release 4.2 Reference Manual. Numerical Algorithms Group, Oxford, UK.

Gibb, M. J. 1998. Animal grazing/intake terminology and definitions. Pasture ecology and animal intake, Pages 21-37 in Proc. Work- 
shop on Pasture Ecology and Animal Intake. September, 1996. M. G. Keane and E. G. O'Riordan, ed., Occasional Publ. No. 3. Concerted Action, AIR-CT93-0947, Dublin, Ireland.

Gibb, M. J., C. A. Huckle, R. Nuthall, and A.J. Rook. 1999. The effect of physiological state (lactating or dry) and sward surface height on grazing behaviour and intake by dairy cows. Appl. Anim. Behav. Sci. 63:269-287.

Hodgson, J., and A. W. Illius, ed. 1996. The Ecology and Management of Grazing Systems. CAB Int., Wallingford, UK.

Howery, L. D., D. W. Bailey, G. G. Ruyle, and W. J. Renken. 2000. Cattle use visual cues to track food locations. Appl. Anim. Behav. Sci. 67:1-14.

Huckle, C. A., R. Nuthall, and M. J. Gibb. 1994. The use of shortterm weight changes to measure intake rates in grazing dairy cattle. Pages 157-158 in Fourth Research Meeting, Br. Grassland Soc., Reading, UK.

Illius, A. W., I. J. Gordon, D. A. Elston, and J. D. Milne. 1999. Diet selection in goats: a test of intake-rate maximisation. Ecology 80:1008-1018.

Kenward, M. G. 1994. A method for comparing profiles of repeated measurements. Appl. Stat. 36:296-308.

Lima, S. L., and L. M. Dill. 1990. Behaviour decisions made under the risk of predation: a review and prospectus. Can. J. Zool. 68:619-640.

Merry, R. J., D. K. Leemans, and D. R. Davies. 2002. Improving the efficiency of silage-N utilisation in the rumen through the use of perennial ryegrasses high in water-soluble carbohydrate content. Proc. XIIIth Int. Silage Conf. SAC, Auchincruive, Ayr, Scotland, UK.

Newman, J. A., A. J. Parsons, J. H. M. Thornley, P. D. Penning, and J. R. Krebs. 1995. Optimal diet selection by a generalist grazing herbivore. Func. Ecol. 9:255-268.

Orr, R. J., S. M. Rutter, P. D. Penning, and A. J. Rook. 2001. Matching grass supply to grazing patterns for dairy cows. Grass Forage Sci. 56:352-361.

Parsons, A. J., J. A. Newman, P. D. Penning, A. Harvey, and R. J. Orr. 1994. Diet preference of sheep: effects of recent diet, physiological state and species abundance. J. Anim. Ecol. 63:465-478.
Penning, P. D., and G. E. Hooper. 1985. An evaluation of the use of short-term weight changes in grazing sheep for estimating herbage intake. Grass Forage Sci. 40:79-84.

Penning, P. D., M. J. Gibb, A. J. Parsons, R. J. Orr, and A. Harvey. 1998. Behavioural and physiological factors limiting intake by grazing ruminants. Pages 10-20 in Pasture Ecology and Animal Intake: Proceeding of a Workshop on Pasture Ecology and Animal Intake held in Dublin on September 24-25, 1996. M. G. Keane and E. G. O'Riordan, ed. Concerted Action AIR3-CT93-0947, Dublin, Ireland.

Piggins, D., and C. J. C. Phillips. 1996. The eye of the domesticated sheep with implications for vision. Anim. Sci. 62:302-308.

Rook, A. J., and P. D. Penning. 1991. Synchronizing of eating, ruminating and idling activity by grazing sheep. Appl. Anim. Behav. Sci. 32:157-166.

Rutter, S. M. 2000. 'Graze': A program to analyse recordings of the jaw movements of ruminants. Behav. Res. Methods Instrum. Comput. 31:86-92.

Rutter, S. M., R. A. Champion, and P. D. Penning. 1997. An automatic system to record foraging behaviour in free-ranging ruminants. Appl. Anim. Behav. Sci. 54:185-195.

Rutter, S. M., R. J. Orr, and A. J. Rook. 2000. Dietary preference for grass and white clover in sheep and cattle: an overview. Pages 73-78 in Grazing Management: The Principles and Practice of Grazing, for Profit and Environmental Gain, within Temperate Grassland Systems, A.J. Rook and P.D. Penning, ed. Occasional Syposium No. 34, Br. Grassland Soc., Reading, UK.

Rutter, S. M., R. J. Orr, P. D. Penning, N. H. Yarrow, and R. A. Champion. 2002. Ingestive behaviour of heifers grazing monocultures of ryegrass or white clover. Appl. Anim. Behav. Sci. 76:1-9.

Rutter, S. M., R. J. Orr, N. H. Yarrow, and R. A. Champion. 2004 Dietary preference of dairy heifers grazing ryegrass and white clover, with and without an anti-bloat treatment. Appl. Anim. Behav. Sci. 85:1-10.

Senft, R. L., M. B. Coughenour, D. W. Bailey, O. E. Sala, and D. M. Swift. 1987. Large herbivore foraging and ecological hierarchies. BioScience 37:789-799. 